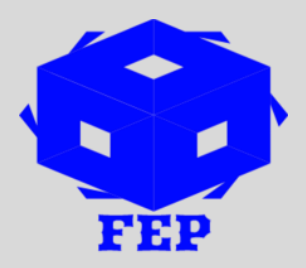

\title{
INTRODUCTION TO CHINA PAKISTAN ECONOMIC CORRIDOR AND ITS IMPORTANCE FOR PAKISTAN
}

Rabia Anam ${ }^{1}$

${ }^{1}$ Institute of Management Sciences, Peshawar, Pakistan

*Corresponding Author: Rabia Anam

Article Received: 16-05-19

Accepted: $25-08-19$
Published: 05-09-19

Licensing Details: Author retains the right of this article. The article is distributed under the terms of the

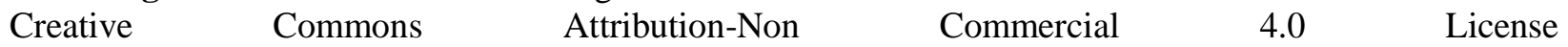
(http://www.creativecommons.org/licences/by-nc/4.0/) which permits non-commercial use, reproduction and distribution of the work without further permission provided the original work is attributed as specified on the Journal open access page.

\section{ABSTRACT}

The China Pakistan Economic Corridor (CPEC) consists of various projects related to energy, telecommunication, and highways linking Gwadar Port to China thus creating a shorter route. This route has strategic importance as it provide cost effective way of exporting Chinese products to the world market and reducing transportation cost on oil imported from Middle East to China. The CPEC project is beneficial for Pakistan as it has potential to reduce country's energy shortage, boost economic growth, create jobs and reduce poverty. The challenges to the project include security issues, political will, and foreign interference. It is recommended that government of Pakistan include key stakeholders such as local people, communities, Chinese government, and neighboring countries in the process in order to better overcome these challenges.

Keywords: CPEC, Pakistan, China, Economy, Growth.

\section{INTRODUCTION}

China is a global emerging economic and political superpower. It is one of the fastest developing country having high influence on the world and its future. Pakistan is sharing its small border with China which makes this superpower our neighboring country. Mr. Xi Jingping, the President of the People's Republic of China visited Pakistan in 2013 which resulted in further strengthening the friendship between the both countries. In May, 2013, a memorandum was signed between Pakistan and China about China-Pakistan Economic Corridore (CPEC). Based on this project, China agreed to make investment of $\$ 46$ billion in Pakistan for upgrading Pakistani infrastructure under the CPEC Projects. The project is part of the China's larger 
strategic plan known as One Belt One Road initiative (OBOR) which is to link China with Asia, Middle East, Africa and even European countries for better access to these markets for its products. The CPEC project is specific to Pakistan and is part of this larger project.

The CPEC project is based on making investment in logistic, infrastructure, energy, telecommunication sector in order to improve Pakistan capability. One aspect of the project is to create a link Gwadar Port (Arabian Sea) to Kashgar in China passing through the great Himalayas on its ways. The investment in energy sector is expected to increase electricity production in Pakistan by more than ten thousand megawatts using different energy sources including hydro, solar, wind, and coal. Other notable projects includes up-gradation of Gwadar International Airport, development of Lahore-Karachi motorway, Hazara Motorway, Havelian Dry Port, and so on.

The CPEC project in Pakistan face a lot of challenges including corruption, security issues, foreign interference, and political victimization. For example, there are several incidents already occurred related to killing of innocent labor working in remote areas related to the CPEC project. In this paper, we look in to such challenges as well as opportunities and threats related to the CPEC project.

\section{Strategic Importance of Gwadar Port}

Gwadar was used to be a sea food village and known as area very much under developed. It used to be owned by the State of Oman until 1954 and later Pakistan formally purchased this area for payment of US\$ 3 million. There was no port or similar in this area until 2002 when General Pervez Musharaf take initiative to develop this place by construction of Gwadar Port. The Phase I of the construction was started in 2002 and completed successfully in 2006 (Holmes, 2013). The phase II was started in 2007 and completed in 2008. In Phase II, it involved construction of $200 \mathrm{~m}$ adaptable wharf along with 5 Kilo Meter long approaching channels. Initially, Gwadar Port was operated by Singapore Authority International and later Pakistani owned organization named 'Gwadar Port Authority' took control of management and running of the organization. Now Chinese Overseas Port Holding Company (2013) is also responsible for management and operational tasks of the port. First ship emarked on the port was in 2008 named PoS Glory bringing 75000 metric tons of wheat.

The strategic importance of the Gwadar is that it is connected to the Arabian sea as well as Indian sea and from the port, movement of regional powers marine activity. It is also important from protection of resources transportation routes. Almost $80 \%$ of world trade ships carrying oil and other useful material use Arabian Sea and this port can play very important role in this. If managed properly, it can be used to provide trade gateway to China, India, Central Asian Republics (CAR) and Russia which signifies its importance. For Central Asian Republics such as Turkemanistan, Uzbekistan, and even Afghanistan, it can provide a route to ship oil and gas products to the Western world using this channel which can be much shorter than any other route possible. The port is highly important to China and the huge investment in Pakistan under CPEC project is an evidence of this (Times of Islamabad, 2016). The Chinese has high interest in this port because currently it is using a longer route to export its products to Middle East and 
European markets while use of this route can save a lot of money and other resources (Din, et al., 2009). According to Garver (2012), the importance of Gwader is that it can reduce the Chinese products transportation cost to half.

Furthermore, China import oil in quantity of about 6 million barrels per day which travels a longer route to get to China and cost more money; whereas, use of Gwadar port and subsequently entry in to China from Kashgar will reduce the oil import related transportation cost which is another benefit for Chinese government. The military importance of this port is that it can provide mean to keep eye on other superpowers including India and USA.

In this project, the Pakistani interest is that CPEC can create thousands of job opportunities for Pakistani labor, can boost tax generation, GDP growth and other favorable advantages. An advantage of the CPEC project is that it can improve Pakistani energy generation infrastructure which will reduce energy shortage. This fact need to be kept in mind that Pakistan is a country which face severe energy shortage and power breakdown is common across its cities and rural areas. The benefit of the CPEC project include the following;

China is going to spend above $\$ 30$ billion for improvement of the power sector in the country. It is expected that there will be more than 16000 Mega Watt electricity added in to national grid in upcoming years. This increased electricity generation will overcome Pakistan electricity shortage and will boost the industry and subsequently the economy of the country.

Improvement in communication infrastructure development is also part of the CPEC project. It is expected that Pakistan road, railway, and air travel will improve after the infrastructural improvement made part of the CPEC project.

Industrial sector growth is also an opportunity for Pakistan since it is expected that a lot of foreign direct investment will flow in to Pakistan as part of the CPEC project. The increased FDI inflow in Pakistan from China as well as other countries also interested in CPEC projects such as Saudi Arabia is expected to improve labor skills and reduce unemployment and poverty.

\section{Role of Major Regional Countries}

As discussed above, Pakistan is facing high challenges including for its CPEC Projects. One of the key challenge is the security of the CPEC project and its related routes. For Pakistan, the substantial security challenge is its neighboring countries including India and Afghanistan. Besides security situation, there is also a need for stabilizing the Pakistani political system and its institutions. In this situation, China can play important role in giving assistance in terms of securing the CPEC project.

Iran is also a regional player and it is also working on developing its own port named as Chahbahar port. For Iran, the CPEC can be a good opportunity if they link it with their Chahbahar port and can take advantage of it mutually. However, so far, India is known to be making huge investment in Chahbahar project which means that Iran will be more under influence of India compare to joining CPEC project of Pakistan. Iran can still use CPEC project to send its oil and related products to India, and Russia. 


\section{Recommendations}

It is recommended that $\mathrm{CPEC}$ and its related challenges may be overcome. One issue is the environmental degradation possibly caused by the CPEC project. Government of Pakistan need to look in to this factor as well. Other challenges such as security and political support also need to be handled appropriately. Involvement of all key stakeholders is important and will benefit the project in the long term. Local staff may be hired in order to improve benefits driven towards local community residing on the route of CPEC.

\section{References}

Din, M. U., Ghani, E., \& Qadir, U. (2009). Recent Experience and Future Prospects of Pakistan's Trade with China. The Lahore Journal of Economics, 14, 87

Garver, J. W. (2012). The diplomacy of a rising China in South Asia. Orbis, 56(3), 391-411.

Holmes, J. R. (2013). Gwadar and the „, String of Pearls“. The Diplomat, 9.

Times of India (2016). Available from https://timesofislamabad.com/cpec-list-of-early-harvestprojects-to-be-completed $\neg$ by-201 